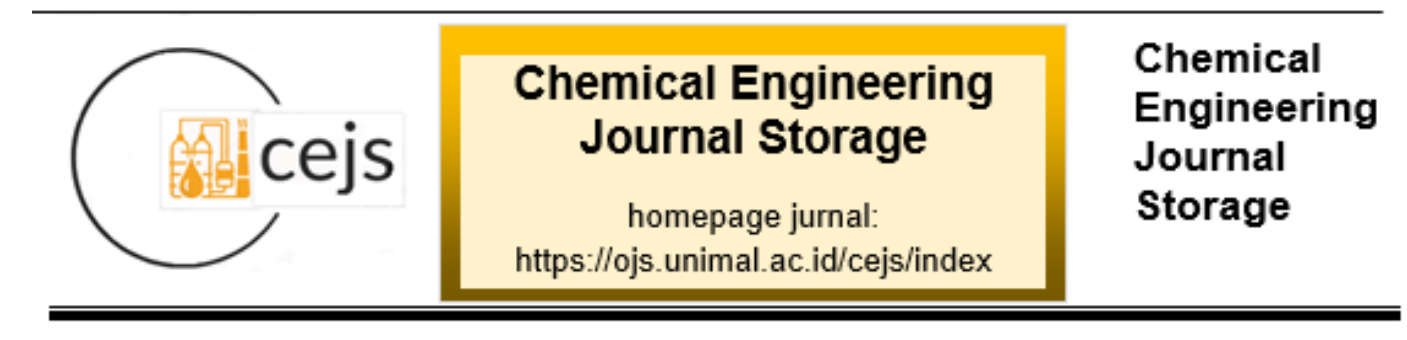

\title{
PENGARUH SUHU DAN WAKTU TERHADAP PROSES PENYULINGAN MINYAK SEREH WANGI (Cimbopogon nardus $I_{\text {.) }}$
}

\author{
Junita Adiandasari, Wusnah, , Azhari \\ Jurusan Teknik Kimia, Fakultas Teknik Universitas Malikussaleh, \\ 24352, Aceh Utara, Indonesia. \\ Email:wusnah@unimal.ac.id
}

\begin{abstract}
ABSTRAK
Ekstraksi adalah suatu proses pemisahan suatu zat berdasarkan perbedaan kelarutannya terhadap dua cairan tidak saling larut yang berbeda. Pengambilan ekstrak minyak atsiri dapat dilakukan dengan tiga metode yaitu penyulingan atau destilasi, ekstraksi menggunakan pelarut, dan melalui pengepresan atau penekanan.Pada percobaan ini metode yang digunakan untuk mengekstrak minyak dari daun sereh wangi dilakukan dengan cara penyulingan. Adapun tujuan dari percobaan ini yaitu untuk mengetahui pengaruh waktu dan suhu penyulingan pada proses pengambilan minyak atsiri. Adapun prosedur penelitian dimulai dengan ukuran daun sereh diperkecil terlebih dahulu. Kemudian ditimbang sereh sebanyak $500 \mathrm{gram}$. Dimasukkan air sebanyak $500 \mathrm{~mL}$ sebagai pelarut, setelah itu baru ditambahkan daun sereh wangi kedalam alat penyulingan. Proses penyulingan dilakukan pada suhu $120^{\circ} \mathrm{C}$ dengan variasi waktu penyulingan $(3,3,5,4,4,5$ dan 5$)$ jam. Hasil penyulingan kemudian dilakukan pemisahan, untuk memisahkan air yang masih terkandung didalam minyak. Ulangi prosedur diatas dengan suhu yang berbeda. Hasil dari penelitian yang didapat yaitu \% yield yang terendah didapat pada waktu 3 jam dengan suhu $120{ }^{\circ} \mathrm{C}$ yaitu $0,998 \%$ dan $\%$ yield tertinggi didapat pada waktu 5 jam dan pada suhu $120^{\circ} \mathrm{C}$ yaitu $1,228 \%$. Sedangkan nilai densitas yang terendah diperoleh pada waktu penyulingan 5 jam yaitu $0,882 \mathrm{gr} / \mathrm{ml}$ dan nilai densitas tertinggi diperoleh pada waktu 3 jam yaitu $0,886 \mathrm{gr} / \mathrm{ml}$.
\end{abstract}

Kata Kunci: Ekstraksi, Penyulingan, Yield, Densitas, Daun Sereh Wangi

\begin{abstract}
Extraction is a process of separating a substance based on the difference in solubility of two different insoluble liquids. Extracting essential oils can be done in three methods, namely distillation or distillation, extraction using solvents, and pressing or pressing. In this experiment the method used to extract oil from leaves of fragrant lemongrass is done by distillation. The purpose of this experiment is to determine the effect of distillation time and temperature on the process of extracting essential oils. The research procedure starts with the size of lemongrass leaves being reduced first. Then weighing 500 grams of lemongrass. Add $500 \mathrm{~mL}$ of water as a solvent, then add lemongrass leaves to the distiller. The distillation process was carried out at a temperature of $120{ }^{\circ} \mathrm{C}$ with variations in distillation time 3 hours, 3.5 hours, 4 hours, 4.5 hours and 5 hours. The distillation is then separated, to separate the water that is still contained in the oil. Repeat the procedure above with a different temperature. The results of the research obtained were the lowest\% yield obtained at 3 hours with a temperature of $120{ }^{\circ} \mathrm{C}$ which was $0.998 \%$ and the highest\% yield was obtained at 5 hours and at a temperature of $120{ }^{\circ} \mathrm{C}$ ie $1.282 \%$. While the lowest density value obtained at the time of 5 hours distillation is $0.882 \mathrm{gr} / \mathrm{ml}$ and the highest density value obtained at 3 hours is $0.886 \mathrm{gr} / \mathrm{ml}$.
\end{abstract}

Keywords: Extraction, Distillation, Yield, Density, Fragrant Citronella Leaves

\section{PENDAHULUAN}

Indonesia merupakan negara yang memiliki keanekaragaman tumbuhan yang dapat dimanfaatkan sebagai salah satu sumber minyak atsiri. Kebutuhan minyak atsiri dunia semakin meningkat seiring dengan 
meningkatnya perkembangan industri modern seperti industri parfum, kosmetik, makanan, aroma terapi dan obat-obatan (Feriyanto, 2013).

Salah satu tanaman obat yang sering diuji dan digunakan adalah sereh wangi (Cymbopogon nardus). Sereh wangi memiliki senyawa aktif yang dapat digunakan untuk pengobatan seperti antibakteri, antifungi dan antiinflamasi (Chooi, 2008). Salah satu senyawa aktif yang terdapat pada sereh wangi adalah sitronelal yang terkandung dalam minyak atsirinya yang memiliki aktivitas antibakteri (Agustian dkk, 2007).

Selain untuk pengobatan, minyak atsiri sereh wangi sering diproduksi oleh perusahan atau pabrik untuk memenuhi kebutuhan pasar lokal dan internasional sebagai bahan dasar pembuatan kosmetik (Sukamto dkk, 2011). Salah satu senyawa penting pada ekstrak tumbuhan ialah minyak atsiri. Kebanyakan minyak atsiri dari beberapa tumbuhan bersifat aktif sebagai anti bakteri dan anti jamur (Agusta, 2000; Picheansoonthon dan Yupparach, 2007; Nurmansyah, 2001 dan 2010). Sereh wangi atau Cymbopogon nardus. L. termasuk famili Graminae.

Kandungan utama dari minyak atsiri sereh wangi adalah sitronellal, geraniol dan metal heptanol (Soetrisno, 1972). Menurut Burdock (2002) komponen senyawa utama minyak sereh wangi ini terdiri dari sitronelal, sitronellol, dan geraniol.

Luangnarumitchai et al. (2007) memaparkan bahwa kandungan sitronelal, geraniol, dan sitronelol dalam minyak sereh wangi juga mampu menghambat aktivitas bakteri.

Tanaman sereh wangi yang mudah tumbuh bisa bayak dimanfaatkan oleh para petani untuk meningkatkan nilai jualnya, karena memiliki kandungan minyak atsiri yang sangat berguna, khususnya untuk industri-industri yang berbahan baku minyak atsiri.

Sebelumnya telah dilakukan penelitian terhadap ekstraksi minyak atsiri dengan bahan baku yang digunakan adalah sereh wangi dengan menggunakan pelarut aseton, $\mathrm{N}$-heksana dan metanol, dengan suhu ekstraksi $50^{\circ} \mathrm{C}$ dan waktu 2, 4, 6, 8 dan 10 jam (Fransiska, dkk., 2008). Pengaruh lama penyulingan terhadap rendemen dan mutu minyak atsir daun sereh wangi (Sentosa, 2004).

Pada penelitian kali ini peneliti ingin lebih mengembangkan proses pengambilan miyak atsiri dengan metode penyulingan sederhana dan pelarut yang digunakan adalah air. Dari penelitian ini sangat diharapkan bisa menghasilkan minyak sereh wangi dengan kuantitas dan kualitas yang lebih baik.

\section{METODOLOGI}

\subsection{Bahan dan Alat}

Bahan yang digunakan adalah daun sereh wangi(Cimbopogon nardus l.) sebanyak 500 gram dan air sebanyak $500 \mathrm{ml}$. Alat utama yang digunakan adalah Seperangkat alat penyulingan, seperangkat alat distilasi, erlenmeyer, neraca analitik, pipet volume, gelas Ukur, beaker glass, thermometer.

\subsection{Prosedur Kerja}

Adapun prosedur kerja pada penelitian ini adalah:

1. Daun sereh diperkecil terlebih dahulu.

2. Kemudian ditimbang sereh sebanyak 500 gram.

3. Dimasukkan air sebanyak $500 \mathrm{~mL}$, setelah itu baru ditambahkan daun sereh wangi kedalam alat penyulingan.

4. Proses penyulingan dilakukan pada suhu $120^{\circ} \mathrm{C}$ dengan variasi waktu penyulingan $(3,3,5,4,4,5$ dan 5) jam.

5. Hasil penyulingan kemudian dilakukan pemisahan, untuk memisahkan air yang masih terkandung didalam minyak.

6. Ulangi prosedur diatas dengan suhu yang berbeda.

\subsection{Tahap Analisa}

\subsubsection{Analisis Densitas}

Piknometer terlebih dahulu dibersihkan dengan cara membilas. Kemudian piknometer dikeringkan dan ditimbang. Piknometer diisi dengan cairan yang dihasilkan dengan suhu sekitar $20^{\circ} \mathrm{C}$ dan dipasang tutupnya. Setelah itu piknometer yang diisi cairan diletakkan diatas neraca untuk ditimbang. Hitung densitas dengan menggunakan rumus:

$$
\rho=\frac{\operatorname{mass} a(g r)}{\operatorname{Volume}(m l)} .
$$

\subsubsection{Menghitung (\%) Yield}

Minyak sereh wangi yang telah dipisahkan dari pelarut, ditimbang beratnya dan diukur volumenya. Dari berat minyak sereh wangi yang diperoleh, di hitung yield minyak sereh wangi. Adapun rumus untuk menghitung yield sebagai berikut:

Yield $(\%)=\frac{\text { massa minyak sereh } \text { wangi }}{\text { massa sereh } \text { wangi }} \times 100 \% \ldots \ldots$. 


\subsubsection{Uji Kelarutan dalam Alkohol}

$1 \mathrm{ml}$ minyak sereh wangi di masukkan kedalam beaker glass $100 \mathrm{ml}$. Kemudian dimasukkan alkohol kedalam buret. Selanjutnya ditambahkan setetes demi setetes alkohol kedalam beaker glass sambil di kocok sampai bening. Volume alkohol yang digunakan dibaca sampai larutan tersebut menjadi bening. Perbandingan minyak sereh wangi larut kedalam etanol $80 \%$ yaitu $1: 2$ jernih, dan seterusnya jernih (SNI, 1995).

\section{HASIL DAN PEMBAHASAN}

3.1 Hasil

Adapun hasil yang didapatkan setelah melakukan penelitian yaitu sebagai berikut:

Hasil penyulingan minyak atsiri dari daun sereh wangi dapat dilihat pada Tabel 3.1.

Tabel 3.1 Hasil Penyulingan Minyak Atsiri dari Daun Sereh Wangi

\begin{tabular}{|l|l|l|c|}
\hline \begin{tabular}{l} 
Suhu $\begin{array}{l}\text { Penyulin } \\
\text { gan }\left({ }^{\circ} \mathrm{C}\right)\end{array}$ \\
\hline \multirow{4}{*}{120}
\end{tabular} & $\begin{array}{l}\text { Waktu } \\
\text { Penyuling } \\
\text { an (jam) }\end{array}$ & $\begin{array}{l}\text { Yield } \\
(\%)\end{array}$ & $\begin{array}{c}\text { Densitas } \\
(\mathrm{gr} / \mathrm{ml})\end{array}$ \\
\cline { 2 - 4 } & 3,5 & 0,998 & 0,886 \\
\cline { 2 - 4 } & 4 & 1,058 & 0,884 \\
\cline { 2 - 4 } & 4,5 & 1,128 & 0,880 \\
\cline { 2 - 4 } & 5 & 1,208 & 0,876 \\
\hline \multirow{4}{*}{130} & 3 & 1,038 & 0,882 \\
\cline { 2 - 4 } & 3,5 & 1,078 & 0,888 \\
\cline { 2 - 4 } & 4 & 1,144 & 0,886 \\
\cline { 2 - 4 } & 4,5 & 1,222 & 0,882 \\
\cline { 2 - 4 } & 5 & 1,228 & 0,878 \\
\hline
\end{tabular}

\subsubsection{Pembahasan}

Percobaan ini bertujuan untuk mengetahui pengaruh waktu dan suhu penyulingan pada proses pengambilan minyak atsiri. Pada percobaan ini sampel yang digunakan adalah daun sereh wangi. Terlebih dahulu dilakukan pengecilan ukuran pada daun sereh wangi.

Tujuan dari pengecilan ukuran daun sereh wangi yaitu untuk memperbesar luas permukaan sehingga kontak antara sampel dan pelarut akan semakin sering terjadi dan memudahkan minyak sereh wangi tersebut terekstrak.

Pengambilan ekstrak minyak atsiri dapat dilakukan dengan tiga metode yaitu penyulingan atau destilasi, ekstraksi menggunakan pelarut, dan melalui pengepresan atau penekanan. Pada percobaan ini metode yang digunakan untuk mengekstrak minyak dari daun sereh wangi dilakukan dengan cara penyulingan.

Daun sereh wangi yang digunakan sebanyak 500 gram dengan menggunakan air sebagai pelarut sebanyak $500 \mathrm{ml}$. Proses penyulingan dilakukan dengan memvariasikan waktu penyulingan $(3,3,5,4,4,5$ dan 5) jam dengan suhu penyulingan $\left(120^{\circ} \mathrm{C}\right.$ dan $\left.130{ }^{\circ} \mathrm{C}\right)$. Warna minyak atsiri dari daun sereh wangi yang diperoleh melalui proses penyulingan dengan menggunakan pelarut air awalnya berwarna jernih, tetapi setelah teroksidasi dengan udara menghasilkan warna kuning kecoklatan. Hal ini mengidentifikasikan bahwa komponen kimia yaitu senyawa citronella, granial, neral dan $\beta$-myrcene terekstrak oleh pelarut air, karena senyawa tersebut mempunyai ciri berwarna kuning hingga kecoklatan (Onawunmi, 1989).

Kelarutan suatu senyawa dalam pelarut tergantung pada sifat polaritas senyawa dan pelarut tersebut. Minyak atsiri yang terkandung dalam daun sereh wangi (Cimbopogon nardus I.) dikenal dengan nama citral, sifat dari senyawa citral itu sendiri yaitu pada suhu kamar berupa cairan berwarna kuning kecoklatan yang mudah menguap, tidak larut dalam air dan larut dalam alkohol dan ester. Senyawa citral ini memiliki aroma yang khas dari daunsereh itu sendiri dan banyak digunakan sebagai zat additive pada sabun dan sebagai bahan dasar untuk pembuatan hidroksi sitronellal dan mentol sintesis. Maka dari itu minyak atsiri dari daun sereh wangi ini tergolong besifat non polar.

Sudarmadji, dkk (1996) juga menuliskan bahwa bahan-bahan dan senyawa kimia mudah larut dalam bahan pelarut yang sama polaritasnya dengan bahan yang dilarutkan, sehingga suatu senyawa akan mudah larut dalam pelarut yang memiliki beda polaritas yang tidak terlalu besar (Phuong, 2008).

Berdasarkan perbedaan perlakuan dapat diketahui kondisi operasi yang baik untuk dapat menghasilkan minyak atsiri dalam jumlah yang lebih banyak, dan diperoleh suatu gambaran pengaruh dari kedua variabel tersebut terhadap hasil minyak atsiri yang diperoleh melalui proses penyulingan dari daun sereh wangi.

Warna merupakan parameter penting dalam menetukan kualitas minyak. Intensitas warna ditentukan oleh banyak/sedikitnya kandungan pigmen warna tertentu didalam minyak. Warna minyak atsiri yang baru 
diekstrak biasanya tidak berwarna atau kekuning-kuningan, tetapi ada juga yang berwarna kemerah-merahan, hijau dan coklat, tergantung dari jenis tanaman yang di ekstrak.

Minyak atsiri apabila dibiarkan lama berkontak dengan udara dan terkena sinar matahari maka minyak dapat menjadi gelap, bau berubah, lama kelamaan mengental dan akhirnya terbentuk resin. Pada analisa warna dilakukan pengamatan secara visual, yaitu membandingkan minyak hasil penyulingan dengan hasil dari SNI 06-3953-1995 sebagai parameter penentuan mutu minyak sereh wangi. Adapun hasil pengamatan yang didapat yaitu warna minyak sereh wangi berwarna kuning kecoklatan. Hal ini menunjukkan bahwa minyak yang didapat sesuai dengan SNI yang telah ditetapkan.

\subsubsection{Pengaruh Suhu dan Waktu Penyulingan Terhadap Yield}

Adapun grafik hubungan pengaruh antara suhu dan waktu penyulingan terhadap yield dapat dilihat pada Gambar 3.1.

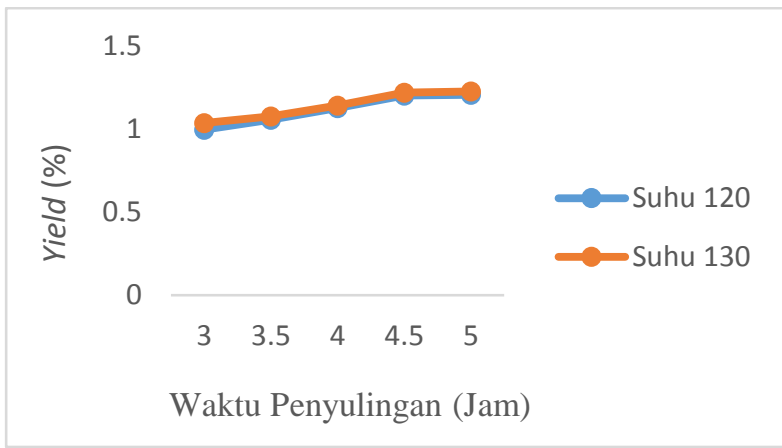

\section{Gambar 3.1 Pengaruh Suhu dan Waktu Penyulingan Terhadap Yield}

Dari Gambar 3.1 dapat dilihat bahwa semakin lama waktu penyulingan yield minyak sereh wangi yang dihasilkan akan semakin meningkat. Hal ini disebabkan karena waktu kontak antara pelarut dengan bahan yang akan diekstrak semakin lama, dan laju difusi pelarut kedalam padatan menjadi lebih besar menyebabkan yield minyak sereh wangi yang dihasilkan juga semakin besar.

Semakin lama proses penyulingan, semakin banyak panas yang diterima oleh bahan sehingga proses difusi semakin meningkat. Menurut Rusli (1977), semakin lama bahan disuling, semakin banyak uap air berhubungan dengan minyak didalam bahan sehingga minyak yang tersuling semakin banyak. Tetapi semakin lama bahan disuling, maka rendemen yang dihasilkan akan semakin menurun. Hal ini disebabkan karena suhu dan tekanan meningkat sehingga rendemen minyak menurun karena terjadi proses polimerisasi yang menghasilkan polimer-polimer dengan berat molekul yang lebih tinggi (Ketaren dan B. Djatmiko, 1978).

Kecepatan keluarnya minyak pada saat penyulingan dipengaruhi oleh beberapa faktor, yaitu titik didih, besarnya tekanan uap yang digunakan, berat molekul dari masing-masing komponen dalam minyak dan kecepatan minyak keluar dari bahan (Ketaren, 1985). Selain itu faktor faktor penyulingan, kadar air bahan juga berpengaruh terhadap rendemen minyak, sehingga sebelum disuling dilakukan pelayuan untuk mengurangi kadar air bahan. Menurut Genjor (1978), rendemen minyak atsiri dipengaruhi oleh cara penanganan sebelum dan sesudah disuling dan cara penyulingan. Munurut Ma'mun et al (1993), pelayuan dapat meningkatkan rendemen air dan kadar minyak karena semakin tinggi suhu bahan sehingga semakin banyak jumlah air yang menguap dan bersamaan dengan menguapnya minyak atsiri.

Dari Gambar 3.1 juga dapat dilihat perbedaan yield minyak sereh wangi yang dihasilkan terhadap lama waktu penyulingan yang berbeda. Dari Gambar 3.1 dapat dilihat yield minyak sereh wangi yang didapat berkisar antara $0,98 \%-1,22 \%$. Dari penelitian ini minyak sereh wangi yang diperoleh sesuai dengan literatur yang ada yaitu $0,5 \%-1,2 \%$ (Ketaren dan Djatmiko, 1978).

Bila diamati dari masing-masing percobaan dapat disimpulkan bahwa, semakin lama waktu penyulingan maka yield yang diperoleh semakin tinggi sampai lama penyulingan tertentu yield ini tidak akan bertambah. Semakin lama waktu penyulingan maka yield minyak sereh wangi yang didapat akan semakin naik, hal ini di sebabkan karena semakin banyaknya panas yang diterima oleh bahan dan semakin banyak uap yang berhubungan dengan sel-sel minyak pada jaringa bahan, maka minyak yang terekstrak semakin banyak. Di samping itu semakin lama waktu penyulingan maka semakin banyak panas yang diterima dan proses difusi akan meningkat sehingga proses penyulingan semakin dipercepat (Rusli, 1977).

Dari Gambar 3.1 terlihat bahwa yield akan meningkat seiring dengan kenaikan suhu operasi penyulingan. Hal ini terjadi karena, semakin tinggi suhu maka pergerakan air lebih besar karena energi kinetik antar molekul meningkat dan kenaikan suhu dalam proses penyulingan dapat mempercepat proses difusi, sehingga dalam keadaan seperti itu seluruh minyak atsiri yang terdapat dalam jaringan tanaman akan terekstrak dalam jumlah yang banyak. Akan tetapi suhu yang digunakan pada proses penyulingan juga tidak boleh terlalu tinggi, karena apabila terlalu tinggi akan menyebabkan minyak atsiri pada daun sereh wangi tersebut akan terdekomposisi (Guenther, 1987). 


\subsubsection{Pengaruh Suhu dan Waktu Penyulingan Terhadap Densitas}

Nilai berat jenis minyak atsiri didefinisikan sebagai perbandingan antara berat minyak dengan berat air pada volume air yang sama pula. Berat jenis sering dihubungkan dengan fraksi berat komponen-komponen yang terkandung didalamnya. Semakin besar fraksi berat yang terkandung dalam minyak, maka semakin besar pula nilai densitasnya (Sudarmadji, 1996).

Berat jenis minyak meningkat seiring dengan peningkatan waktu penyulingan, karena komponenkomponen yang mempunyai titik didih tinggi membutuhkan waktu yang lebih lama untuk terdistilasi jika dibandingkan dengan komponen-komponen bertitik didih rendah. Semakin lama waktu penyulingan maka akan terjadi peningkatan konsentrasi minyak yang disebabkan oleh semakin banyaknya akumulasi komponenkomponen kimia penyusun minyak atsiri, baik itu senyawa yang bertitik didih tinggi maupun bertitik didih rendah.

Peningkatan berat jenis minyak juga dapat terjadi karena proses pemanasan yang berlangsung selama proses penyulingan. Pemanasan menyebabkan sebagian kecil komponen minyak atsiri mengalami polimerisasi. Komponen-komponen minyak atsiri yang mengalami polimerisasi adalah dari golongan senyawa hidrokarbon takteroksigenasi seperti senyawa terpen.

Pemanasan dengan menggunakan suhu dan tekanan tinggi akan menyebabkan sejumlah komponen berantai panjang yang memiliki titik didih tinggi ikut tersuling bersama minyak. Fraksi berat tersebut seperti parafin, lilin dan senyawa resin. Parafin merupakan senyawa dari golongan alkana berantai panjang yang terdapat dalam jaringan lemak tanaman aromatik kemudian larut bersama minyak atsiri. Semakin lama waktu penyulingan maka akan meningkatkan konsentrasi berat jenis minyak (Hernani, 2006).

Adapun grafik hubungan pengaruh antara suhu dan waktu penyulingan terhadap densitas dapat dilihat pada Gambar 3.2.

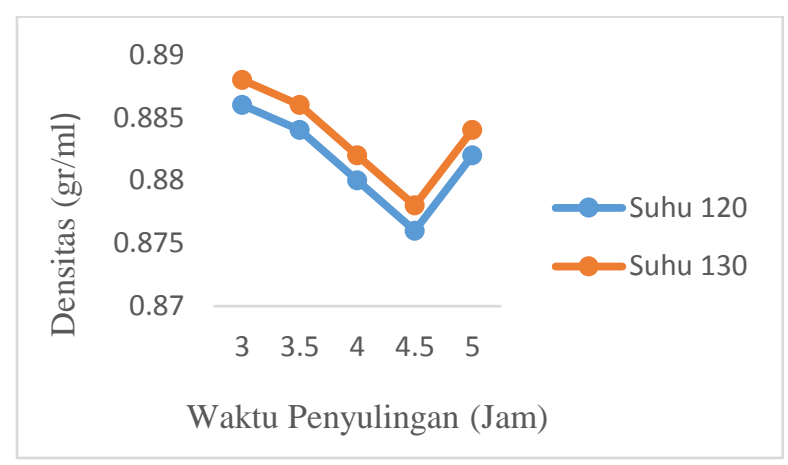

Gambar 3.2 Pengaruh Suhu dan Waktu Penyulingan Terhadap Densitas

Dari Gambar 3.2 dapat dilihat bahwa semakin lama waktu penyulingan maka densitasnya akan semakin kecil sampai batas lama waktu penyulingan 4,5 jam, dan akan naik pada waktu penyulingan 5 jam. Turunnya densitas sampai batas lama waktu penyulingan disebabkan oleh naiknya kadar graniol dan cironellal sampai lama waktu penyulingan 4,5 jam. Citronellal dan graniol adalah petunjuk kemurnian minyak sereh wangi. Jadi semakin banyak graniol dan citronellal maka minyak tersebut akan semakin murni.

Dari Gambar 3.2 juga dapat dilihat semakin tinggi suhu maka densitas yang didapat semakin tinggi. Pada Gambar 3.2 terlihat bahwa pada waktu penyulingan 5 jam densitas menjadi makin naik, hal ini disesebabkan karena pada waktu penyulingan 5 jam graniol dan cittronellal akan terpolimerisasi sehingga kemurnian minyak akan turun akibat terbentuknya polimer-polimer dengan berat molekul yang lebih tinggi (Sentosa, 2004).

Pada penelitian ini nilai densitas yang diperoleh antara 0,876-0,888 sesuai dengan standar mutu SNI 06-3953-1995 yang ada yaitu 0,875-0,922 gr/ml.

\subsubsection{Uji Kelarutan dalam Alkohol}

Uji kelarutan dalam etanol memberi gambaran apakah suatu minyak larut atau tidak dalam alkohol. Semakin mudah larut minyak dalam etanol maka semakin banyak kandungan senyawa polar dalam minyak (Susetyo dan Reni, 2004). Setelah dilakukan pengujian di laboratorium teknik kimia kelarutan minyak sereh wangi dalam etanol yaitu 1:2 yang berarti $1 \mathrm{ml}$ minyak sereh wangi larut dalam $2 \mathrm{ml}$ etanol. Alkohol merupakan gugus hidroksil $(\mathrm{OH})$, karena itu alkohol dapat larut dalam minyak atsiri (Susetyo dan Reni, 2004).

Menurut Guenther (1952), bahwa kelarutan minyak atsiri dalam alkohol ditentukan oleh jenis komponen kimia yang terkandung didalam minyak atsiri. Penurunan kelarutan minyak dalam alkohol tergantung pada jenis komponen-komponen kimia yang terkandung dalam minyak. Semakin banyak komponen senyawa yang mengandung gugus $\mathrm{OH}$ maka semakin tinggi kelarutannya, sebaliknya semakin sedikit senyawa terpen maka semakin tinggi kelarutannya. Hal ini dapat disimpulkan bahwa semakin besar kelarutan minyak atsiri pada alkohol maka kualitas minyak atsiri tersebut semakin baik (Sastrohamidjojo, 2002). 


\section{4.}

\section{KESIMPULAN}

Berdasarkan hasil penelitian dan pembahasan, maka dapat diambil kesimpulan sebagai berikut:

1. Semakin lama waktu penyulingan maka \% yield yang didapat semakin tinggi, akan tetapi nilai densitas minyak semakin rendah atau menurunkan minyak atsiri.

2. Semakin tinggi suhu penyulingan maka \% yield yang didapat juga semakin tinggi.

3. Semakin lama waktu penyulingan sampai batas yang ditentukan, akan menurunkan mutu dari minyak tersebut.

4. Minyak sereh wangi yang dihasilkan memiliki kualitas yang baik dari segi \% yield, densitas dan kelarutan dalam alkohol yaitu rata-rata sudah memenuhi standar SNI.

\section{DAFTAR PUSTAKA}

Agusta, A., 2000. Minyak Atsiri Tumbuhan Tropika Indonesia. Penerbit ITB: Bandung.

Agustian, E., Sulaswaty, A., Laksmono, J.A., Adilina, LB. 2007. Pemisahan Sitronellal dari Minyak Sereh Wangi Menggunakan Unit Fraksionasi Skala Bench. J. Tek. Ind. Pert. Vol. 17 (2): 49-53.

Badan Standarisasi Nasional, 1995. Minyak Sereh. Standar Nasional Indonesia. SNI 06-3953-1995. Hal 3-5: Jakarta.

Burdock, G. 2002. Fanarali's Handbook of Flavor Ingredients. Boca Raton, FL, CRC Press.

Chooi, O.H. 2008. Remppah Ratus: Khasiat makanan dan ubatan. Prin-Ad SDN. BHD, Kuala Lumpur. Hal: 202-203.s

Feriyanto, Y. 2013. "Pengambilan Minyak Atsiri dari Daun dan Batang Sereh Wangi (Cymbopogon winterianus) Menggunakan Metode Distilasi Uap Air dengan Pemanasan Microwave". Jurnal Teknik Kimia. Institut Teknologi 10 November: Surabaya.

Fransiska, A. Laurentia Eka, S. Felycia Edi, S. 2008. Ekstraksi Minyak Atsiri Dari Tanaman Serah Denga Menggunakan Pelarut Metanol, Aseton dan N-Heksana. Fakultas Teknik Jurusan Teknik Kimia. Universitas Katolik Widya Mandala: Surabaya.

Genjor, J., 1978. Von Der Duftenden Blume Ylang-ylang. Philippinische Marrchen.

Guenther, E. 1952. The Essential Oils. $2^{\text {nd }}$ Ed. New York: D. Van Nostrand Co. Inc.

Guenther, E. 1987. Minyak Atsiri Jilid I. Diterjemahkan oleh S. Ketaren. Jakarta.Universitas Indonesia Press.

Hernani dan T. Marwati. 2006. Peningkatan Mutu Minyak Atsiri Melalui Proses Pemurnian. Makalah disampaikan pada konferensi nasional minyak atsiri 2006, Solo 11 hal.

Ketaren S. 1985. Minyak Atsiri. IPB: Bogor.

Ketaren, S dan B. Djatmiko. 1978. Minyak Atsiri Bersumber Dari Bunga dan Buah. Bogor: Departemen Teknologi Hasil Pertanian, Fatemeta IPB.

Luangnarumitchai, S., Lamlertton, S., dan Tiyaboonchai, S., 2007. Antimicrobial Activity Of Essential Oils Againts Five Strains of Propionibacterium Acnes.Mahidol University Journal of Pharmaceutical Sciences, Volume 34(1-4), 60-64.

Ma'mun dan Nanan N. 1993. Pengaruh Perajangan dan lama pelayuan terhadap rendemen dan mutu minyak serai dapur. Buletin Penelitian Tanaman Rempah dan Obat. Vol. 8 (1).

Nurmansyah dan H. Syamsu. 2001. Pengaruh minyak atsiri beberapa klon unggul serai wangi terhdap pathogen penyakit layu dan busuk batang tanaman cabe. Stigma IV (4): 362.

Nurmansyah. 2010. Efeksifitas Minyak Serai Wangi Dan Fraksi SitronellalTerhadap Pertumbuhan Jamur Phytopthora Almivora Penyebab Penyakit Busuk Buah Kakao. Bul. Littro. 21 (1): 43-45

Onawunmi, G.O. 1989. Evaluation of The Antimicrobial of Citral, Left. Appl. Microbial. Vol. 9, HIm. 105-108.

Phuong Ha, H., Hunynh. March 2008. Extraction of Essential oil From Lemongrass Using Supercritical Carbondioxidem. Chemical Engineering Departement De La Salle University: Manila. 
Rusli, S. 1977. Kontruksi Unit Penyulingan Sereh Wangi, Sereh Dapur dan Cengkeh, Lembaga Penelitian Tanaman Industri.

Sastrohamidjojo, H. 2002. Kimia Minyak Atsiri. Yogyakarta: FMIPA, Universitas Gadjah Mada.

Sentosa, Ginting. 2004. Pengaruh Lama Penyulingan Terhadap Rendemen dan Mutu Minyak Atsiri Daun Sereh Wangi. Fakultas Pertanian. Universitas Sumatera Utara.

Soetrisno R. 1972. Ichtisar farmakognosi.Edisi III.Tunas Harapan Jakarta.

Sudarmadji, S., Haryono, B., Suhardi. 1996. Analisa Bahan Makanan dan Pertanian. Liberty: Yogyakarta.

Sukamto dan Dzajuli M Suheryadi Dedi. 2011. Serai Wangi cimbopogon nordus I.) sebagai penghasil minyakatsiri,tanaman konservasi, dan pakan lemak. Rosiding seminar nasional inovasi perkebunan. Bogor

Susetyo R., dan Reni H. 2004. Kiat Menghasilkan Minyak Sereh Wangi: Jakarta, 